\title{
Chapter 13 \\ Early Career Casual Teachers: The Role of Relationships with Colleagues in Negotiating a Teacher Identity and Developing Resilience
}

\section{Helen Dempsey, Caroline F. Mansfield, and Judith MacCallum}

\begin{abstract}
Developing relationships with colleagues has been identified as one way to enhance teacher resilience and assists in negotiating a professional identity. For early career teachers, opportunities to participate in induction and mentoring programmes and engage in professional learning can assist in developing these relationships. However, for early career teachers who can only obtain casual work and work intermittently often in many different schools, these opportunities may be limited. This chapter presents longitudinal, qualitative research that explores how early career casual teachers negotiated their teacher identity. Drawing on data from focus groups, semi-structured interviews and reflective tasks, the chapter shares insights into how relationships are pivotal in the development of a strong teacher identity.
\end{abstract}

Keywords Early career casual teachers $\cdot$ Teacher identity $\cdot$ Resilience

\subsection{Introduction}

Negotiation and construction of a professional identity is a complex and ongoing process, and incorporates both how a person sees themselves and how others perceive them (Alsup 2006). Opportunities to develop relationships with colleagues, school administrators, students and parents is an important component of negotiation and construction process (Barkhuizen 2016; Pearce and Morrison 2011). As developing relationships with colleagues has been identified as one way to enhance teacher resilience (Le Cornu 2013; Mansfield et al. 2014; Mansfield et al. 2016)

H. Dempsey $(\varangle) \cdot$ J. MacCallum

Murdoch University, Perth, WA, Australia

e-mail: h.dempsey@murdoch.edu.au

J. MacCallum

e-mail: j.maccallum@murdoch.edu.au

C. F. Mansfield

The University of Notre Dame Australia, Fremantle, WA, Australia

e-mail: Caroline.mansfield1@nd.edu.au 
this chapter explores the experiences of early career casual teachers in developing these relationships whilst negotiating a professional identity.

Early career teachers are increasingly finding their initial employment as a casual teacher, which can influence their development of a professional identity (Preston 2019). Developing a strong professional identity plays an important role in teachers' commitment and engagement with the profession, along with their capacity to sustain motivation (Day and $\mathrm{Gu}$ 2010). However, professional identity for early career casual teachers is particularly complex as they are negotiating and constructing their professional identity as teachers as well as casual workers (Charteris et al. 2015).

Despite the challenges faced by early career casual teachers, resilience may be considered a factor in their ongoing commitment to the profession and effectiveness in their teaching (Gu and Day 2007). Gu and Day (2007) identified sustaining a strong sense of vocation and the development of self-efficacy were key characteristics of resilience. Resilience is more than just "bouncing back" from adversity and one of the key protective factors which contribute to resilience is the opportunity to develop relationships with colleagues (Mansfield et al. 2014) and therefore understanding how early career casual teachers develop supportive relationships with colleagues needs to be explored.

\subsection{Literature Review}

In order to understand how resilience, casual teaching and professional identity are linked literature which ties these ideas together has been reviewed. This review starts by considering one aspect of resilience, building relationships, which appears to act as a protective factor. As relationship building is considered important for resilience literature regarding challenges faced by early career casual teachers may give some insights into their ability to develop relationships with colleagues. Following on from this the literature linking relationships and professional identity is explored. In particular the links between opportunities to develop relationships with students and colleagues and the impact on professional identity negotiation and construction.

Building effective relationships can be seen as important for developing a strong professional identity but relationship building is also a protective factor of developing resilience (Beltman et al. 2011; Le Cornu 2013). It appears that despite challenges faced by early career teachers, when they have built strong relationships with not only students but colleagues and leadership then resilience is enhanced. For early career casual teachers though, opportunities to develop strong relationships can be compromised as they may teach at a school infrequently and even if returning to a school may be in different classes therefore making it difficult to develop relationships with students and teaching teams. Research suggests that both colleagues and students grant a different status to casual teachers, with a common terminology used being babysitter (Ewing 2001; McCormack 2005; Pietsch and Williamson 2007). There may be a perception of casual teachers as being transitory, potentially further impacting their opportunities to develop relationships with students and colleagues. 
Casual teaching can be challenging but for early career teachers these challenges can be exacerbated due to difficulties finding work, limited support and opportunities to engage with others, in part due to the casual nature of their work (Preston 2019). The first concern for early career casual teachers is finding employment (Bamberry 2011; Brock and Ryan 2016) and lack of employment appears to be linked to early career teacher attrition. Dupriez et al. (2015) study of 19,196 early career teachers in Belgium showed that whose working for less than 3 months of the year were 8.5 times more likely to leave the profession than those working for the whole year.

Another challenge for early career casual teachers is access to support as it appears that they are rarely offered opportunities to participate in professional learning or have access to mentors (Bamberry 2011; Colcott 2009; Jenkins 2015; Nicholas and Wells 2016). Participation in professional learning is considered a necessary support for all early career teachers (Larsen and Allen 2016; Le Cornu 2013, Mansfield and $\mathrm{Gu} 2019$ ) as without access to professional learning early career casual teachers may regress in relation to skills and knowledge (Pietsch 2011). Besides formal professional learning opportunities, access to mentors as a form of professional learning is rarely provided to early career casual teachers (Jenkins 2015; McCormack and Thomas 2005). Research suggests that lack of support for early career teachers leads to dissatisfaction which is then linked to intentions to leave the profession (Kelly et al. 2018). It could be inferred then that early career casual teachers are at particular risk of dissatisfaction and attrition due to lack of support available to them. Therefore, developing relationships is a particularly important protective factor in order to develop resilience in early career casual teachers.

It may be argued that development of a strong professional identity is important (Day 2008) given the risk of attrition of early career casual teachers (Dupriez et al. 2015). Not only has a strong professional identity contributed to developing resilience (Gu and Day 2007) it has helped teachers remain committed to the profession (Avalos and Aylwin 2007; Day 2011; Day and Gu 2010; Morrison 2013). Professional identity also contributes to teacher effectiveness by enhancing teachers' self-efficacy and motivation (Alsup 2006; Chong 2011) and can be seen as "how teachers regard themselves in relation to the community of teachers to which they belong" (Day and $\mathrm{Gu} 2014$, p. 55). For early career teachers, professional identity is negotiated and constructed through social interactions between themselves and colleagues, students and other members of the school community (Barkhuizen 2016; Pearce and Morrison 2011). Such interactions are crucial for teachers attempting to find a way to fit in with the culture of the school (Anderson and Cohen 2015; Chong 2011; Wilkins et al. 2012). However due to the fragmented nature of casual teaching, professional identity of early career casual teachers may be constrained (Pietsch and Williamson 2007).

As teacher professional identity is negotiated and constructed through interactions with significant others, it is important to discuss the different sites where interactions occur for teachers. Firstly, the key site of these influential interactions is the classroom. For early career teachers, managing student abilities, engaging students in their learning and motivating their students have been reported as key influences on professional identity construction (Avalos and Aylwin 2007) as well as students 
affording them the status of teacher (McNally and Blake 2012). Although the relational component of teachers' work contributed to a sense of success and satisfaction (Schuck et al. 2012), student-teacher relationships are recognised as dynamic and regularly change (Le Cornu 2013). However, for early career casual teachers fragmented employment means that there are limited opportunities to develop these relationships (Trotter and Wragg 1990). Fragmented employment may then impact on their opportunities to be afforded the status of teacher.

The next key site of professional identity construction and negotiation is the school community. Research suggests that discourses between early career teachers and more experienced teachers provide affordances or constraints in the conceptualisation and negotiation of roles and identities (Haddy 2009; Hsieh 2010; Morrison 2013). Teacher identity literature also affirms the important role of mentors in assisting early career teachers' negotiation and construction of a professional identity (Pillen and Beijaard 2009; Urzua and Vasquez 2008), however as noted early career casual teachers have limited access to mentors. Considering the limited opportunities to interact with colleagues or mentors, this may lead to challenges constructing a professional identity.

The final site of professional identity negotiation and construction is the broader professional community. Gee (2008) suggested that labels and titles were a way of identifying people and groups of people and assigning them roles, although these labels might constrain identity negotiation and construction. Early career teachers are often assigned titles such as probationary teacher (Rippon and Martin 2006), provisional teacher (Teacher Registration Board of Western Australia 2019a) or novice teacher (Saka et al. 2013), which suggest the teacher is "not quite" a teacher. Whilst all early career teachers are given these labels, for those employed as casual teachers they are likely to spend a longer period of time with this label as the transition from provisional to fully registered can be challenging for casual teachers due to the regulatory requirements (Teacher Registration Board Western Australia 2019b).

\subsection{Methodology}

A qualitative, longitudinal research project was undertaken using a case study approach. All participants were early career casual teachers in Western Australia, with no more than three years' teaching experience and participants were both primary and secondary teachers (see Table 13.1).

The research was conducted in two phases, with Phase One being a series of focus groups, with findings from this phase informing the task topics and the statements for sorting for interview two in Phase Two. In Phase Two, five participants were interviewed three times over the course of several months with reflective tasks being completed between interviews, as outlined in Fig. 13.1. Phase Two provided an opportunity for professional identity to be explored in more depth. In both phases participants completed a questionnaire including demographic information as well as details of the amount of professional learning, access to mentor, numbers of days 
Table 13.1 Participant gender and school setting by phase

\begin{tabular}{l|l|l|l}
\hline Phase & School setting & Male & Female \\
\hline \multirow{2}{*}{1} & Primary & 1 & 9 \\
\cline { 2 - 4 } & Secondary & 2 & 6 \\
\hline \multirow{2}{*}{2} & Primary & 1 & 2 \\
\cline { 2 - 4 } & Middle years (4-9) & & 1 \\
\cline { 2 - 4 } & Secondary & & 1 \\
\hline
\end{tabular}
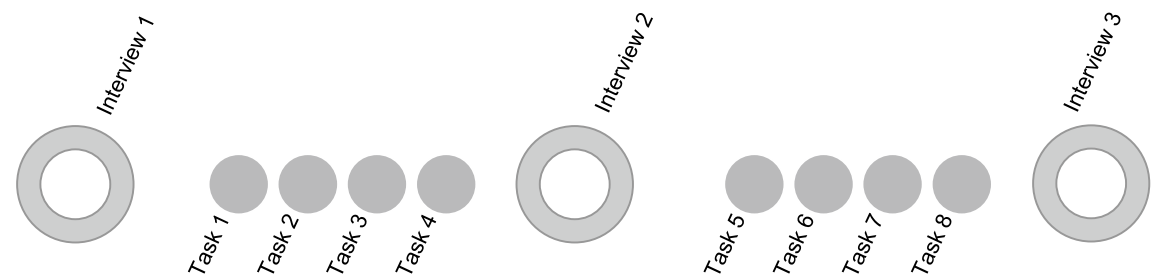

Fig. 13.1 Design of phase two

generally worked in a week and how they obtained employment in order to gain an insight into this detail without impacting on the time participants could share their experiences.

Themes explored during both phases are outlined in Table 13.2. Phase 1 and Interview 1 of Phase Two focussed mainly on understanding the experiences of the participants related to their work, and opportunities for developing relationships with colleagues and students. In the second interview of Phase Two, the focus was on understanding the aspects of "teachers" work' they engaged with as well as their perception of their professional identity. Participants were asked to arrange teaching activities (such as preparing meaningful work, interacting with colleagues, planning and assessing student work) and then discussed their placement of each activity within their arrangement, which afforded them the opportunity to discuss their perceptions of the work they engaged with as a casual teacher. The same technique was used when identity was explored, using words such as babysitter, teacher, "just a relief teacher', isolated, as these were statements found in the literature. Identity was further explored in Interview Three when participants were presented with a variety of images of teachers, including teachers working with small groups, overwhelmed with paperwork, standing at the font of a class teaching, feeling frustrated with student behaviour and asked to talk about the images and reflect on whether the images related to their perception of themselves as teachers. In the final interview participants also discussed their reflective tasks and how their experiences, ideas or feelings had changed over time. This was particularly relevant for the concept of identity, as identity is perceived in the literature as fluid and negotiated through experiences (Day and Gu 2007; Hong 2010).

An initial coding trial used descriptive coding (Saldaña 2013), with words or short phrases used to identify the topic of the selected data from individual questions 
Table 13.2 Themes explored in each Phase

\begin{tabular}{l|l}
\hline Focus of questions & Phase two component \\
\hline Experiences of work, professional learning, relationships & Interview 1 + Phase 1 \\
\hline $\begin{array}{l}\text { Experiences of work (choose a day and record what happens on that } \\
\text { day) }\end{array}$ & Task 1 \\
\hline People who give support (support in both personal and professional life) & Task 2 \\
\hline $\begin{array}{l}\text { Professional learning (what they had access to and the relevance for } \\
\text { their teaching context) }\end{array}$ & Task 3 \\
\hline $\begin{array}{l}\text { People discuss teaching (who they talk to about teaching, what did they } \\
\text { talk about) }\end{array}$ & Task 4 \\
\hline $\begin{array}{l}\text { Tasks teachers do, perceptions of casual teachers (sorting activity, then } \\
\text { discussing placement of statements) }\end{array}$ & Interview 2 \\
\hline $\begin{array}{l}\text { Perceptions of community (asked to define a community of practice } \\
\text { and whether they were part of a COP) }\end{array}$ & Task 5 \\
\hline $\begin{array}{l}\text { Perceptions of self as teacher (what did they do as a teacher, whether } \\
\text { they thought they were a teacher) }\end{array}$ & Task 6 \\
\hline $\begin{array}{l}\text { Perceptions of casual teachers (by parents, students and colleagues) } \\
\text { Future as teacher (what they would be doing in 5 years and why) }\end{array}$ & Task 7 \\
\hline $\begin{array}{l}\text { Perceptions of self as teacher, journey as teacher (viewing images and } \\
\text { discussing their view of themselves as teacher, reviewing their journey } \\
\text { so far) }\end{array}$ & Interview 3 \\
\hline
\end{tabular}

asked in the focus groups (see Table 13.2 for question topics). An initial coding trial used descriptive coding (Saldaña 2013), with words or short phrases used to identify the topic of the selected data from individual questions asked in the focus groups. Data analysis in Phase Two utilised similar strategies to Phase One, although the process differed slightly as an inductive approach was also utilised to ensure any new themes that emerged were included. The impact of regulatory requirements on both emotions and sense of being part of the teacher community emerge through this process. Data from Phase Two were obtained from six individual participants and the data from each participant were coded separately, including interviews, questionnaire and reflective tasks.

This study received ethics approval from the relevant university and all identifying information was anonymised. Participants chose their own pseudonyms which have been used in this chapter.

\subsection{Findings}

The relational aspects of finding employment, working with students and developing relationships with colleagues were key themes throughout this study. These concepts 
Table 13.3 Summary of Strategies used to obtain employment

\begin{tabular}{l|l}
\hline Strategies used to obtain employment & Number of participants $(n=18)$ \\
\hline Providing curriculum vitae (CV) & 15 \\
\hline Through professional experience school & 6 \\
\hline Personal recommendations & 5 \\
\hline Employment agencies & 2 \\
\hline $\begin{array}{l}\text { Graduate teacher employment pool from the department of } \\
\text { education }\end{array}$ & 1 \\
\hline
\end{tabular}

will be discussed from the findings in Phase One, focus group, before a more in-depth discussion of relationships is presented through a case study from Phase Two.

\subsubsection{Role of Relationships in Finding Employment}

There were five key strategies used to gain employment as shown in Table 13.3, however the most common strategy did not necessarily lead to employment.

Although the main strategy used to obtain employment was approaching schools and leaving contact details and a curriculum vitae, participants suggested personal connections were a more successful strategy. These personal connections included prior connections made during professional placements or personal contacts at a school. This is evident from the following statements made during the focus groups.

Teachers are actually responsible for getting their own relief [casual teacher] and they normally get relief [casuals] from people they know (Fran)

I have found schools like to have a number of relief [casual teachers] that they get to know well and the kids get to know (Amy)

Without the interaction with others generated by employment as a teacher it is difficult to develop a professional teacher identity.

\subsubsection{Student-Teacher Relationships}

Developing relationships with students was identified as critical by all participants and many commented that developing relationships with students improved student behaviour. Several strategies were utilised to develop positive relationships with students, including talking to students during supervision:

Especially when you do yard duty [student supervision], you watch them play and then you can say hello again and talk to them. [Jaz]

Furthermore, exploring common interests and finding methods to connect with individual students was helpful in establishing strong relationships with students: 
If they can engage with someone who is interested in them and their interests more importantly, it gives them a reason to want to be in that classroom. [Alex]

Participants specifically mentioned the importance of learning students' names in order to begin developing relationships.

Regular employment contributed positively to relationship building, underpinned by such fundamental strategies as learning students' names, as students were then likely to treat them as a teacher rather than "just a casual teacher". Although building relationships was deemed important it was recognised that it was a product of a daily relationship with students, and for some casual teachers developing relationships was particularly difficult.

I think it is quite hard to build relationships with them. You spend most of the day trying to figure out who is who and their names and everything. [Jane]

Moreover, developing relationships with students was more challenging with sporadic employment.

Progressing student learning and developing relationships with students also contributed to an identity as teacher. When participants sensed they had continued the students' learning rather than handing out worksheets, they identified as being a "teacher ... not there as a babysitter" [Lexi]. These opportunities became more likely when employed regularly. For secondary teachers, working within their curriculum area meant, they felt their curriculum knowledge helped them "continue their [the students'] education" [Michelle], rather than just manage student behaviour. Opportunities to develop relationships with students contributed to "a sense of belonging [Alex] and legitimized their role as a teacher". Furthermore, participant's concepts of a legitimate teacher were of the regular classroom teacher. Teaching experiences that replicated the regular roles and experiences of classroom teachers reinforced their developing teacher identities. For example:

I treat it like my own class. [Alexis]

I expect[ed] them to work even though their usual teacher [was] not there. [Olivia]

\subsubsection{Building Relationships with Colleagues}

Consistent with challenges faced in comprehending tacit practices, sporadic employment resulted in difficulties developing relationships with colleagues. For instance, initiating conversations was challenging, as "it is a bit intimidating when you don't know anybody" [Jade]. At times casual teachers were required to "do duty or had to get things prepared" [Lulu], therefore, had limited "time to go and talk to teachers" [Jaz]. Furthermore, casual employment meant that they were not in one location "long enough to feel part of the community" [Trixie]. Developing relationships began with being acknowledged; however, this varied between schools. Participants discovered that sometimes "every single staff member smiled at me and said hello" [Catherine], 
whereas at other schools, "they don't want to know you" [Alexis]. Whilst opportunities to engage with colleagues varied, participants developed an understanding of "how different schools work and the culture of the schools" [Jane].

By comparison, regular employment or prior connections to a school provided opportunities to develop relationships. Participants stated that employment at professional placement schools, felt "like going home" [Betsie] as they "knew all the teachers and knew [their] way around the school, [and] felt comfortable" [Lexi]. Additionally, regular employment resulted in "know[ing] all [of the teachers] reasonably well to talk to and ask things" [Chloe] and assisted with relationship development. Opportunities existed for conversations to change from a "personal level" to professional discussions. Developing relationships resulted in chances to share resources and collaborate. In particular, participation in professional learning contributed to a sense of efficacy, as:

You feel like you are contributing as well, instead of being the graduate who needs help. [Jade]

\subsection{Case Study: Chloe}

A case study from Phase Two demonstrates in more detail some of the complexities faced by early career casual teachers. This case was chosen as it presents the experiences of Chloe who by her third year of casual teaching had encountered sufficient opportunities to develop relationships with students and colleagues. This case study was reviewed by Chloe to ensure the analysis of her data accurately reflected her contributions and captured her intent.

Chloe completed a one-year Graduate Diploma in Education (Secondary) after spending several years employed as a scientist. She was a mature-age graduate who had changed careers after the birth of her first child and at the time of the study had just had her second child. She was in a financially stable position and tutored high school Mathematics and Science in addition to casual teaching. She had made a choice to work as a casual teacher as she perceived this as "family friendly" as she did not have to do any preparation or marking. At the time of this study Chloe was in her third year after graduation.

As a Mathematics and Science teacher, Chloe had been employed regularly since graduation, initially working at four different schools. After taking a break for maternity leave, Chloe decided to only approach two schools where she worked most often. She found that schools preferred employing "Maths and Science teachers to cover Maths and Science" (Interview 1). So, for Chloe at the point of this study it was a combination of relationships she had developed with schools as well as subject specialisation which contributed to regular employment.

Developing relationships with students was considered a core activity for Chloe and regular employment at one school afforded Chloe opportunities to begin to develop relationships with students and have students regard her as a "teacher". She commented that: 
In terms of relief ... I have now learnt that a big part of [managing the class] is engaging with the students and because I have been at the same school for quite a while, it is forming relationships with students. (Interview 2)

For Chloe engaging students and attempting to develop relationships was particularly important when teaching out of field as she was "less able to assess whether [the students] were able to go ahead with the task they had been set" (Interview 2). Despite her sense of competence, she still considered that opportunities to develop relationships with students and therefore student behaviour was different for casual teachers due to her intermittent participation with individual classes.

Chloe considered collaborating with colleagues and developing relationships with colleagues depended mainly on gaining regular employment at a school. She found that early in her teaching she had not developed any relationships with other teachers, which led to feelings of isolation.

Early on ... I didn't have any close relationships to teachers at the school and was really feeling isolated and on the periphery and really didn't know how to progress. (Interview 2)

Regular employment, however, assisted Chloe in developing relationships with colleagues, which contributed to her decision to continue seeking employment at one particular school. Although she felt valued by the school community, she did not have a sense that she had the same connection as a permanent teacher.

When you are there you are there and when you are not there it is not necessarily going to be noticed. (Interview 2)

Once employed regularly at a school, Chloe discovered that her colleagues in the Maths and Science departments treated her as a teacher and she was able to collaborate with them in teaching the Maths and Science content.

I am quite close with the maths and the science teachers at the school ... they know it is not just relief or babysitting. So they will give you content to, actually real content to teach and move on with. (Interview 2)

Continued regular employment then deepened the collaboration between Chloe and her regular colleagues.

You talk about how the class is going with them, so you have that real content conversation and pedagogy but linked to the content ... you get that change in thinking how they are looking at you (Interview 3).

She found that she had started to feel a sense of belonging and felt valued by her colleagues, which contributed greatly to her sense of competence as a teacher and consolidated her identity as one.

Interestingly, it was the relationships that Chloe had developed at one school that assisted in making connections in the broader teaching community. She was able to access the Graduate Teacher Professional Learning Program developed by the Department of Education. This programme provided her with a department email which then unlocked additional resources only available on the secure section of the Department of Education website. Chloe noted prior to this she "felt quite separate 
from the teaching community" (Task 5). This access to resources and connection with the employer beyond the school level also consolidated her developing identity. As a result, Chloe had a strong sense of self-efficacy and was developing a strong sense of vocation, both key characteristics of resilience.

\subsection{Discussion}

The relational aspect associated with gaining access to both school and professional communities was a new insight that emerged from this study. Previous research on casual teaching has suggested that casual teachers, and particularly early career casual teachers, experience difficulties accessing work (Bamberry 2011; Brock and Ryan 2016; Jenkins et al. 2009) managing student behaviour (Jenkins et al. 2009; Pietsch and Williamson 2007) and accessing professional learning (Bamberry 2011; Colcott 2009; Lunay and Lock 2006). Whilst this was affirmed by this study, results also suggested that relationships assisted in gaining access to both school and professional communities.

It appears that early career casual teachers were more successful in gaining employment if they had developed relationships with members of a school community, however this did not always result in regular or sustained employment. This research found that relationships developed during professional experience assisted early career casual teachers to gain access to school communities as teachers, as was the case for several of the participants. Although the importance of relationships in gaining employment has not been emphasised in previous research regarding early career casual teachers, this was similar to the findings that principals preferred to employ casual teachers already known to the school (Crittenden 1994). It might be that opportunities to demonstrate competency during professional experience assisted early career teachers in their pursuit of employment as literature suggests that schools value competency and flexibility in their casual teachers (Charteris et al. 2015; Junor 2000). Without access to employment as a teacher, a professional identity as teacher is unlikely. Therefore, with the increasing number of early career teachers beginning their professional working lives as casual teachers, initial teacher education providers could highlight the importance of developing relationships with colleagues and administrators in schools for pre-service teachers during their final professional experience and emphasise the range of benefits associated with them.

In both phases of this study, participants indicated that they placed great emphasis on developing relationships with students. Participants mentioned a variety of strategies used to develop these relationships including learning students' names, finding out about their interests and talking to students during break times. Fielder's (1991) findings indicate that casual teachers who experience less challenging student behaviour personalised their interactions with students by using names, and it is important to note that this strategy was used by several participants. These relationship-building strategies provide opportunities for engagement between students and early career casual teachers in a socialising manner that supports and 
complements their teaching. In Phase Two, participants perceived engaging with students, controlling the class and developing relationships with students as their core activities, although this may be related to their limited opportunities to participate in other teacher work. The importance placed on developing relationships with students contrasts to other research regarding casual teachers, including early career casual teachers. When considering student-teacher interactions, a majority of research suggests that managing student behaviour was a key concern for early career casual teachers (Jenkins et al. 2009; McCormack and Thomas 2005; Pietsch and Williamson 2007), which is a similar finding for all early career teachers (Friedman 2000). However, is has been noted that early career teachers find developing relationships with students assist in managing challenging behaviour (Hirschkorn 2009), but this has not been noted in the literature related to early career casual teachers. In addition, opportunities to develop relationships with students may contribute to early career casual teachers being given the status of teacher by the students and thereby contributing to the early career casual teachers' perception of themselves as teacher rather than babysitter.

Developing relationships with colleagues was dependent on opportunities to engage with staff in both informal and professional contexts. Participants found interacting with colleagues challenging, in part due to lack of time to interact with colleagues which they felt was needed in order to develop relationships. These findings are supported by Jenkins et al.'s (2009) study which shows a link between irregular and sporadic employment and difficulties forming relationships with colleagues for early career teachers. In contrast regular employment provided repeat opportunities to engage in informal conversations as well as professional discussions regarding pedagogy. This finding is unsurprising as research suggests that it is regular employment which affords opportunities to develop relationships with colleagues (Jenkins et al. 2009; McCormack and Thomas 2005). However, when considering that part of the process of professional identity construction is negotiating how they view themselves and how they are viewed by others (Horn et al. 2008), lack of opportunity to interact with colleagues may limit early career casual teachers' ability to develop a strong professional identity. When considering the link between professional identity development and commitment to the profession (Day and $\mathrm{Gu}$ 2010; Morrison 2013) as well as developing resilience (Beltman et al. 2011; Le Cornu 2013) schools and colleagues should consider processes which encourage relationship-building opportunities with and for early career casual teachers.

Providing casual teachers access to professional learning opportunities could enhance opportunities for relationship building. Access to professional learning has been consistently noted as a challenge for casual teachers (Bamberry 2011; Bourke 1993; Jenkins 2015; Lunay and Lock 2006; Nicholas and Wells 2016). This research appears to support this finding as access to professional learning was limited and seemed to rely on early career teachers developing a strong relationship with a school. Whilst some professional learning has been specifically developed for early career teachers by the Department of Education (Department of Education and Training Western Australia 2016) at the time of the study access to this programme required a department email which was not provided to casual teachers. Schools 
could provide casual teachers with access, but it appears that regular employment in one school was needed for this to occur, as in the case of Chloe. The Graduate Teacher Professional Learning Program (GTPLP) enabled early career teachers to engage with colleagues and develop professional judgement and assisted with early career teachers being able to fulfil the regulatory requirement of full registration. Mockler and Sachs (2007) suggest that these types of collegiate incidents might contribute to professional identity negotiation and construction and provide opportunities to improve teaching and learning. Chloe attended the GTPLP and considered this an important factor in improving her teaching. She was reminded of teaching skills explored during her pre-service teacher education and became aware that other early career teachers were struggling with classroom management, even those will full-time teaching employment. This affirms similar findings of Patrick (2008) who discusses the importance of teachers being part of and contributing to a professional community in order to establish their place in the professional and their self-identity as teacher. However, some elements which contribute to teacher identity construction do not appear to be available to casual teachers such as mentoring, peer reviewing of their teaching and performance management (Fraser et al. 2017).

\subsection{Conclusion}

Although this study has provided some key insights into the experiences of early career casual teachers, the findings must be situated within the limitations of this research. Nevertheless, the importance of relationships between early career casual teachers and students and colleagues appears to be an important aspect of their early teaching experience. When considering the link between developing relationships and professional identity negotiation and construction as well as resilience, initial teacher education courses should highlight the importance of developing relationships both at their institution and on the pre-service placements. In addition, schools should be encouraged to provide early career casual teachers with opportunities to interact with colleagues in both formal and informal ways. It is pleasing to note that since this study was undertaken access to professional learning at the Department of Education in Western Australia has been provided to all casual teachers, which is a positive initiative.

\section{References}

Alsup, J. (2006). Teacher identity discourses: Negotiating personal and professional spaces. Urbana, Ill: National Council of Teachers of English.

Anderson, G., \& Cohen, M. (2015). Redesigning the identities of teachers and leaders: A framework for studying new professionalism and educator resistance. Education Policy Analysis Archives, 23, 85. https://doi.org/10.14507/epaa.v23.2086. 
Avalos, B., \& Aylwin, P. (2007). How young teachers experience their professional work in Chile. Teaching and Teacher Education, 23(4), 515-528. https://doi.org/10.1016/j.tate.2006.11.003.

Bamberry, L. (2011). As disposable as the next tissue out of the box: Casual teaching and job quality in New South Wales public school education. The Journal of Industrial Relations, 53(1), 49-64. https://doi.org/10.1177/0022185610390296.

Barkhuizen, G. (2016). Narrative approaches to exploring language, identity and power in language teacher education. RELC, 1-18. https://doi.org/10.1177/0033688216631222.

Beltman, S., Mansfield, C., \& Price, A. (2011). Thriving not just surviving: A review of research on teacher resilience. Educational Research Review, 6(3), 185-207. https://doi.org/10.1016/j.edu rev.2011.09.001.

Bourke, S. (1993). Learning about casual primary teachers in New South Wales. Unicorn, 19(2), 64-71.

Brock, A., \& Ryan, T. G. (2016). Exploring the gap between teacher certification and permanent employment in Ontario: An integrative literature review. Canadian Journal of Educational Adminstration and Policy, 175, 1-28.

Charteris, J., Jenkins, K., Jones, M., \& Bannister-Tyrrell, M. (2015). Discourse appropriation and category boundary work: Casual teachers in the market. Discourse: Studies in the Cultural Politics of Education, 1-19. https://doi.org/10.1080/01596306.2015.1113158.

Chong, S. (2011). Development of teachers' professional identities: From pre-service to their first year as novice teachers. KEDI Journal of Educational Policy, 8(2), 219-233. http://ro.ecu.edu. au/ajte/vol36/iss $8 / 4$.

Colcott, D. (2009). The professional identity of relief teachers. Paper presented at the AARE: International Education Research Conference, Canberra.

Crittenden, A. (1994). Evaluation of the relief teaching programme in government primary schools in Western Australia. Issues in Educational Research, 4(2), 81-93.

Day, C. (2008). Committed for life? Variations in teachers' work, lives and effectiveness. Journal of Educational Change, 9(3), 243-260. https://doi.org/10.1007/s10833-007-9054-6.

Day, C. (2011). Uncertain professional identities: Managing the emotional contexts of teaching. In C. Day \& J. C.-K. Lee (Eds.), New understandings of teacher's work (pp. 45-64). London, UK: Springer.

Day, C., \& Gu, Q. (2007). Variations in the conditions for teachers' professional learning and development: Sustaining commitment and effectiveness over a career. Oxford Review of Education, 33(4), 423-443. https://doi.org/10.1080/03054980701450746.

Day, C., \& Gu, Q. (2010). The new lives of teachers (1st ed.). Oxon, UK: Routledge.

Day, C., \& Gu, Q. (2014). Resilient teachers, resilient schools. London, UK: Routledge.

Department of Education and Training Western Australia. (2016). Institute for Professional Learning. Retrieved from http://det.wa.edu.au/professionallearning/detcms/portal/.

Dupriez, V., Delvaux, B., \& Lothaire, S. (2015). Teacher shortage and attrition: Why do they leave? British Educational Research Journal, 42(1), 21-39. https://doi.org/10.1002/berj.3193.

Ewing, L. A. (2001). Relief teaching in Western Australian primary schools. Unpublished master's thesis, University of Western Australia, Crawley WA.

Fielder, D. J. (1991). An examination of substitute teacher effectiveness. The Clearing House, 64(6), 375-377.

Fraser, K., Greenfield, R., \& Pancini, G. (2017). Conceptualising institutional support for early, mid, and later career teachers. International Journal for Academic Development, 22(2), 157-169. https://doi.org/10.1080/1360144X.2016.1218882.

Friedman, I. A. (2000). Burnout in teachers: Shattered dreams of impeccable professional performance. JCLP/In Session: Psychotherapy in Practice, 56(5), 595-606.

Gee, J. P. (2008). Social linguistics and literacies: Ideology in discourses (3rd ed.). London, United Kingdom: Routledge.

Gu, Q., \& Day, C. (2007). Teachers resilience: A necessary condition for effectiveness. Teaching and Teacher Education, 23(8), 1302-1316. https://doi.org/10.1016/j.tate.2006.06.006. 
Haddy, L. J. (2009). A conversation with Jessica: A dialogic inquiry into the developing literacy practices of a beginning teacher and a reading specialist. Doctoral dissertation. PsycINFO database. (AAI3324331).

Hirschkorn, M. (2009). Student-teacher relationships and teacher induction: Ben's story. Teacher Development: An International Journal of Teachers Professional Development, 13(3), 205-217. https://doi.org/10.1080/13664530903335566.

Hong, J. Y. (2010). Pre-service and beginning teachers' professional identity and its relation to dropping out of the profession. Teaching and Teacher Education, 26(8), 1530-1543. https://doi. org/10.1016/j.tate.2010.06.003.

Horn, I. S., Nolen, S. B., Ward, C. J., \& Campbell, S. S. (2008). Developing practices in multiple worlds: The role of identity in learning to teach. Teacher Education Quarterly (Summer), 61-72.

Hsieh, B. Y. C. (2010). Exploring the complexity of teacher professional identity. Doctoral dissertation, ProQuest Dissertations and Theses Global database. (3445497).

Jenkins, K. (2015). Casual teaching: A significant gap in professional learning. Paper presented at the Conversations on Knowledge for Teaching, Tasmania. http://conversationsonkft.weebly.com/ papers.html/k_jenkins_2015_casual_teaching.

Jenkins, K., Smith, H., \& Maxwell, T. (2009). Challenging experiences faced by beginning casual teachers: Here one day and gone the next! Asia-Pacific Journal of Teacher Education, 37(1), 63-78. https://doi.org/10.1080/13598660802616443.

Junor, A. (2000). 'You don't take sick leave unless you are dying': Casual professionals and precarious work. Education Links, (60), 25-29.

Kelly, N., Sim, C., \& Ireland, M. (2018). Slipping through the cracks: Teachers who miss out on early career support. Asia-Pacific Journal of Teacher Education, 46(3), 292-316. https://doi.org/ 10.1080/1359866X.2018.1441366.

Larsen, E., \& Allen, J. M. (2016). Building professional learning identities: Beginning teachers' perceptions of causality for professional highs and lows. In R. Brandenberg, S. McDonough, J. Burke, \& S. White (Eds.), Teacher education: Innovation, intervention and impact (pp. 231-251). Singapore: Springer.

Le Cornu, R. (2013). Building early career teacher resilience: The role of relationships. Australian Journal of Teacher Education, 38(4), 1-16. https://doi.org/10.14221/ajte.2013v38n4.4.

Lunay, R. G., \& Lock, G. (2006). Alienation among relief teachers servicing government metropolitan primary schools. Issues in Educational Research, 16(2), 171-192.

Mansfield, C., Beltman, S., Broadley, T., \& Weatherby-Fell, N. (2016). Building resilience in teacher education: An evidenced informed framework. Teaching and Teacher Education, 54, 77-87. https://doi.org/10.1016/j.tate.2015.11.016.

Mansfield, C., Beltman, S., \& Price, A. (2014). I'm coming back again! The resilience process of early career teachers. Teachers and Teaching: Theory and Practice, 20(5), 547-567. https://doi. org/10.1080/13540602.2014.937958.

Mansfield, C., \& Gu, Q. (2019). "I'm fnally getting that help that I needed": Early career teacher induction and professional learning. The Australian Educational Researcher, 46(4), 639-659, https://doi.org/10.1007/s13384-019-00338-y.

McCormack, A. (2005). Treat our casuals well, they are gold: Supporting casual beginning teachers of health and physical education. ACHPER Australia Healthy Lifestyles Journal, 52(1), 20.

McCormack, A., \& Thomas, K. (2005). The reality of uncertainty: The plight of casual beginning teachers. Change: Transformations in Education, 8(1), 17-31.

McNally, J., \& Blake, A. (2012). Miss, what's my name?: New teacher identity as a question of reciprocal ontological security. Educational Philosophy and Theory, 44(2), 196-211. https://doi. org/10.1111/j.1469-5812.2010.00642.x.

Mockler, N., \& Sachs, J. (2007). More than 'identity': Tools for the teaching profession in troubled times. Paper presented at the AARE 2006 International education research conference, Adelaide. http://www.aare.edu.au/06pap/moc06579.pdf. 
Morrison, C. (2013). Teacher identity in the early career phase: Trajectories that explain and influence development. Australian Journal of Teacher Education, 38(4), 91-107. http://dx.doi.org/10. 14221/ajte.2013v38n4.5.

Nicholas, M., \& Wells, M. (2016). Insights into casual relief teaching: Casual relief teachers' perceptions of their knowledge and skills. Asia-Pacific Journal of Teacher Education, 1-21. https://doi.org/10.1080/1359866X.2016.1169506.

Patrick, R. (2008). New teachers, professional knowledge and educational reform in New Zealand. Doctoral dissertation. Retrieved from http://hdl.handle.net/10536/DRO/DU:30023296.

Pearce, J., \& Morrison, C. (2011). Teacher identity and early career resilience: Exploring the links. Australian Journal of Teacher Education, 36(1), 48-59. http://dx.doi.org/10.14221/ajte.2011v3 $6 n 1.4$.

Pietsch, M. (2011). Expanding the professional knowledge base of beginning teacher: The influence of differentiated employment experience on the development of competency in teaching. Doctoral dissertation. Retrieved from http://eds.b.ebscohost.com/eds (UTas.b1570902).

Pietsch, M., \& Williamson, J. (2007). 'It's all about experience': The challenge of becoming a teacher in fragmented employment contexts. Paper presented at the annual conference of the Australian Teacher Education Association. Quality in teacher education: Considering different perspectives and agendas. Woolongong, Australia.

Pillen, M., \& Beijaard, D. (2009). Exploring professional identity dilemmas of beginning teachers during the transition period from student to teacher. Paper presented at the 14th Biennial Conference of the International Study Association for Teachers and Teaching (ISATT). Finland.

Preston, B. (2019). Reforming replacement teaching: A game changer for the development of early career teaching? In A. Sullivan, B. Johnson, \& M. Simons (Eds.), Attracting and keeping the best teachers: Issues and opportunities (pp. 161-191). Singapore: Springer Singapore.

Rippon, J., \& Martin, M. (2006). Call me teacher: The quest of new teachers. Teachers and Teaching: Theory and Practice, 12(3), 305-324. https://doi.org/10.1080/13450600500467605.

Saka, Y., Southerland, S. A., Kittleson, J., \& Hutner, T. (2013). Understanding the induction of a science teacher: The interaction of identity and context. Research in Science Education, 43(3), 1221-1244. https://doi.org/10.1007/s11165-012-9310-5.

Saldaña, J. (2013). The coding manual for qualitative researchers (Vol. 2nd). Los Angeles, CA: Sage.

Schuck, S., Aubusson, P., Buchanan, J., \& Russell, T. (2012). Beginning teaching: Stories from the classroom. New York, NY: Springer.

Teacher Registration Board Western Australia. (2019a). Provisional registration. https://www.trb. wa.gov.au/Teacher-Registration/Becoming-registered/Registration-categories/Provisional-Reg istration.

Teacher Registration Board Western Australia. (2019b). Professional standards for teachers in Western Australia. https://trb.wa.gov.au/.

Trotter, A., \& Wragg, T. (1990). A study of supply teachers. Research Papers in Education, 5(3), 251-276.

Urzua, A., \& Vasquez, C. (2008). Reflection and professional identity in teachers' future-oriented discourse. Teaching and Teacher Education, 24(7), 1935-1946. https://doi.org/10.1016/j.tate. 2008.04.008.

Wilkins, C., Busher, H., Kakos, M., Mohamed, C., \& Smith, J. (2012). Crossing borders: New teachers co-constructing professional identity in performative times. Professional Development in Education, 38(1), 65-77. https://doi.org/10.1080/19415257.2011.587883. 
Open Access This chapter is licensed under the terms of the Creative Commons Attribution 4.0 International License (http://creativecommons.org/licenses/by/4.0/), which permits use, sharing, adaptation, distribution and reproduction in any medium or format, as long as you give appropriate credit to the original author(s) and the source, provide a link to the Creative Commons license and indicate if changes were made.

The images or other third party material in this chapter are included in the chapter's Creative Commons license, unless indicated otherwise in a credit line to the material. If material is not included in the chapter's Creative Commons license and your intended use is not permitted by statutory regulation or exceeds the permitted use, you will need to obtain permission directly from the copyright holder.

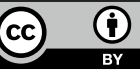

